\title{
Research Article: Benefits received and constraints faced by BDN 711 variety of pigeonpea cultivation in Marathwada region of Maharashtra
}

\author{
S.G. PURI, P.R. DESHMUKH, U.N. ALSE AND D.D. PATAIT
}

Article Chronicle : Received :

23.08.2017;

Revised :

25.09.2017;

Accepted :

12.10.2017

KeY Words :

Benefits, Constraints, BDN 711, Pigeonpea

Author for correspondence :

\section{P.R. DESHMUKH}

Directorate of

Extension Education,

Vasantrao Naik

Marathwada Krishi

Vidyapeeth, PARBHANI

(M.S.) INDIA

See end of the article for

authors' affiliations
SUMMARY : Study was undertaken in Marathwada region of Maharashtra state. Ambajogai and Kaij tehsil of Beed district has purposively selected. From Ambajogai tehsil three villages namely Jawalgaon, Ghatnandur, Kumbephal and in Kaij tehsil three villages namely, Borisawargon, Bansarola, Jawalban were selected purposively. Minimum five respondents from each village thus, comprising of fifty pigeonpea growing farmers were selected by proportionate random sampling method. 78.00 per cent of the respondents had medium (13.61 to $40.64 \mathrm{q}$ ) level of productivity, 84.00 per cent mentioned yield will be increased if followed the different technologies, 68.00 per cent mentioned drip irrigation system will help to increasing yield level. All of the respondents kept their produce for seed purpose and mentioned BDN 711 is a guaranteed crop due to higher productivity and other characteristics of crop, further it was observed that large majority $(80.00 \%$ to $96.00 \%)$ of the respondents felt that BDN 711 variety had no effect of climatic change, intercultural operations are easier due to appropriate growth of plants, resistance for diseases, easier for threshing, suitable for rainfed condition, sustainable in water stress and superior for intercrop. 40.00 per cent of the respondents faced with low knowledge of improved technology and 34.00 per cent of the respondents suggested to provide effective insecticide spraying schedule.

How to cite this article : Puri, S.G., Deshmukh, P.R., Alse, U.N. and Patait, D.D. (2017). Benefits received and constraints faced by BDN 711 variety of pigeonpea cultivation in Marathwada region of Maharashtra. Agric. Update, 12(4): 671-675; DOI : 10.15740/HAS/AU/12.4/671-675. 